\section{Chromosome banding studies in two patients with XXXXY syndrome ${ }^{1}$}

SUMMARY In 2 adult male patients with 49 chromosomes, an XXXXY sex chromosome constitution was confirmed by trypsin-Giemsa banding studies. Clinical findings as well as fingerprint ridge counts were typical of the syndrome. Primary hypogonadism was documented by finding low serum testosterone and raised serum LH and FSH levels. Several radiological abnormalities, not previously described in this syndrome, were seen in 1 patient.

Since the first case was reported in 1960 (Fraccaro et al.), fewer than 100 patients, predominantly infants and children, with the XXXXY syndrome have been described. Though karyotypic analysis has revealed the presence of $\mathbf{3}$ additional $\mathrm{C}$-group chromosomes in all cases, few studies have specifically identified these as $\mathrm{X}$ chromosomes. In this communication, we describe chromosome banding studies in 2 adult

'Supported by Veterans Administration Research Funds and USPHS Grants MCH-927, and HD-04612. patients with the XXXXY syndrome and, additionally, note endocrine and radiological features of potential diagnostic use.

\section{Materials and methods}

Serum LH, FSH, testosterone, and oestradiol were determined in random blood samples by a commercial laboratory using radioimmunoassay methods. Serum prolactin, growth hormone, thyrotropin (TSH), triiodothyronine $\left(T_{3}\right)$, and thyroxine $\left(T_{4}\right)$ were measured by specific radioimmunoassays (Schalch and Parker, 1964; Chopra, 1972; Chopra et al., 1972; Sinha et al., 1974; Pekary et al., 1976).

\section{Case reports}

\section{CASE 1}

A 27-year-old man was seen for evaluation of delayed sexual maturation. Both parents were in good health when the patient was born, his father aged 27 and his mother 25 . The patient had normal older and younger brothers. There was no consanguinity or family history of genetic abnormality, and no drugs or radiation were administered during the pregnancy, which was uneventful. The patient weighed $2400 \mathrm{~g}$ at birth.
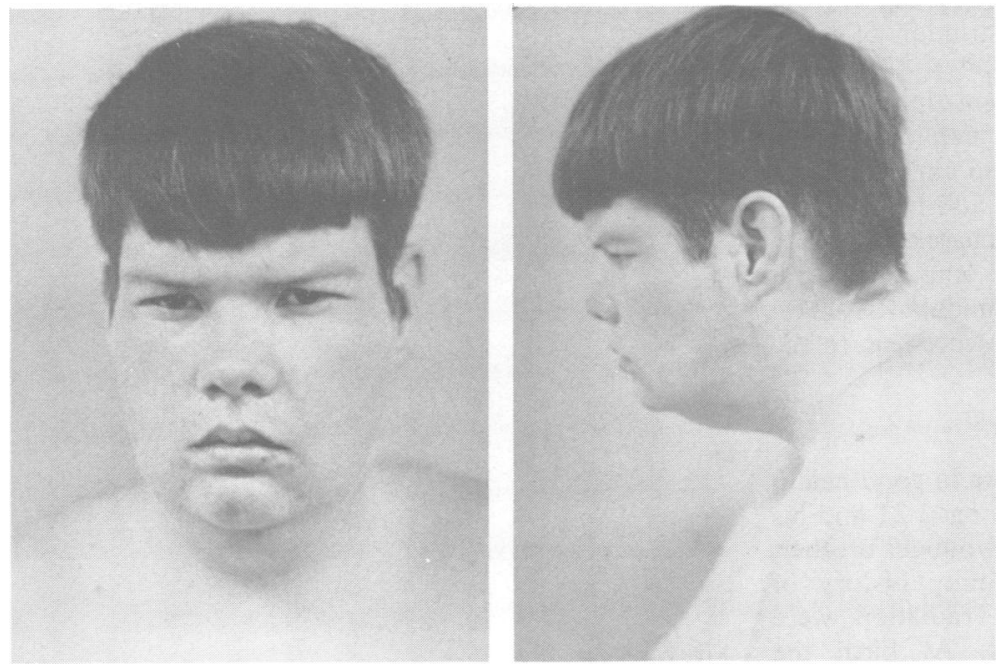

Fig. 1 Case 1. 
Table 1 Clinical and radiological features of $X X X X Y$ syndrome

\begin{tabular}{|c|c|c|c|}
\hline & $\begin{array}{l}\text { Published } \\
\text { reports* }\end{array}$ & Case 1 & Case 2 \\
\hline Mongoloid slant & $71 \%$ & + & No \\
\hline Epicanthal fold & $85 \%$ & + & No \\
\hline Strabismus & $57 \%$ & No & + \\
\hline Broad, flat nose & $96 \%$ & + & + \\
\hline Malformed ears & $78 \%$ & + & No \\
\hline Mental retardation & $100 \%$ & + & + \\
\hline Hypogonadism & $91 \%$ & + & + \\
\hline Small penis & $79 \%$ & + & + \\
\hline Abnormal scrotum & $79 \%$ & No & + \\
\hline Cryptorchidism & $24 \%$ & No & No \\
\hline Cardiac abnormalities & $18 \%$ & No & No \\
\hline Retarded bone age & $89 \%$ & No & No \\
\hline Sclerotic cranial sutures & $57 \%$ & + & NE \\
\hline Prognathism & $47 \%$ & No & + \\
\hline Hypertelorism & $30 \%$ & No & + \\
\hline Radioulnar synostosis & $32 \%$ & + & + \\
\hline Limitation of elbow movement & $89 \%$ & + & + \\
\hline Clinodactyly & $93 \%$ & No & No \\
\hline Capitate corner defect & $83 \%$ & No & NE \\
\hline Scoliosis & $35 \%$ & + & + \\
\hline Thoracic kyphosis & $53 \%$ & + & + \\
\hline Coxa valga & $84 \%$ & No & + \\
\hline Genua valgum & $13 \%$ & No & + \\
\hline Gap between 1 st and 2 nd toes & $55 \%$ & No & NE \\
\hline Pes planus & $54 \%$ & + & + \\
\hline
\end{tabular}

* References: Zaleski et al. (1966); Houston (1967); Tenbrinck et al. (1976). NE, Not examined.

At 6 months of age, it was recognised that he was both physically and mentally retarded; estimated IQ was 50 on specific testing at age 24 . He had spontaneous development of some pubic hair at age 14 , though this remained sparse. He had had facial and truncal acne for several years.

Physical examination in August 1976 revealed a tall, obese, dull appearing man (Fig. 1). Clinical and radiological characteristics are presented in Table 1 . Malformation of the ears consisted of simplification of the external shape and an accessory skin tag in front of each ear. There was bilateral restriction of pronation and supination of the elbow.

Additional findings in this patient include: the presence of only deciduous teeth; eunuchoid proportions with crown-to-pubis length $85 \mathrm{~cm}$ and pubisto-floor $90 \mathrm{~cm}$, and equal arm span and height; fine, tapered fingers and toes; female escutcheon; bilaterally descended testes measuring $0.5 \mathrm{~cm}$ in length; bilateral gynaecomastia with $1 \mathrm{~cm}$ diameter glandular tissue on the left and $2 \mathrm{~cm}$ of glandular tissue eccentric to the nipple on the right.

CASE 2

A 28-year-old man. Both parents were in good health when the patient was born, his father aged 21 and his mother 22. The patient had a normal younger brother. There was no consanguinity or family history of genetic disease, and no drugs or radiation were administered during the pregnancy. At birth the patient weighed almost $2500 \mathrm{~g}$, and bilaterial hip dislocation and bilateral club-foot deformity were $\stackrel{\mathbb{S}}{-}$ noted. Mental deficiency was first recognised at $6 \stackrel{\oplus}{?}$ months of age. The patient had had kidney and bladder stones removed and had also had cataract and $\stackrel{?}{\rightarrow}$ retinal surgery.

Physical examination in November 1976 showed a흠 mildly obese Caucasian man who looked younger than $\frac{\bar{s}}{\vec{\gamma}}$ his age (Fig. 2). Clinical and radiological charac- $\mathbb{\Omega}$ teristics are presented in Table 1. Additional features@ included: a low hairline anteriorly; a torus palatinus; $\rightarrow$ normal dental development; webbed neck; pronounced varus deformities of both heels, with both feet $\vec{\omega}$ fixed in the varus position. Further examination of theo extremities and joints was complicated by previous $\overline{3}$ bone and joint surgery which also altered evaluation of linear growth and skeletal measurements. Hand shape $\vec{r}$ was normal, with fine tapering fingers and interosseous ${ }_{i}^{+}$ muscle wasting. There was a female escutcheon, buto no gynaecomastia. There were areas of alopecia overo the scalp where the patient had been pulling his hair out-a habit of many years. The testes were bi- $\vec{\longrightarrow}$ laterally descended, soft, and measured $1.0 \mathrm{~cm}$ in length. Muscle strength in the lower extremities was conspicuously reduced, but only mildly decreased in the arms. He followed simple commands well but with reluctance. Speech was indistinct.

\section{Dermatoglyphic analyses}

CA S E 1

The right hand had a $t$ palmar axial triradius with a simian crease. The left hand had a $t^{\prime}$ axial triradius

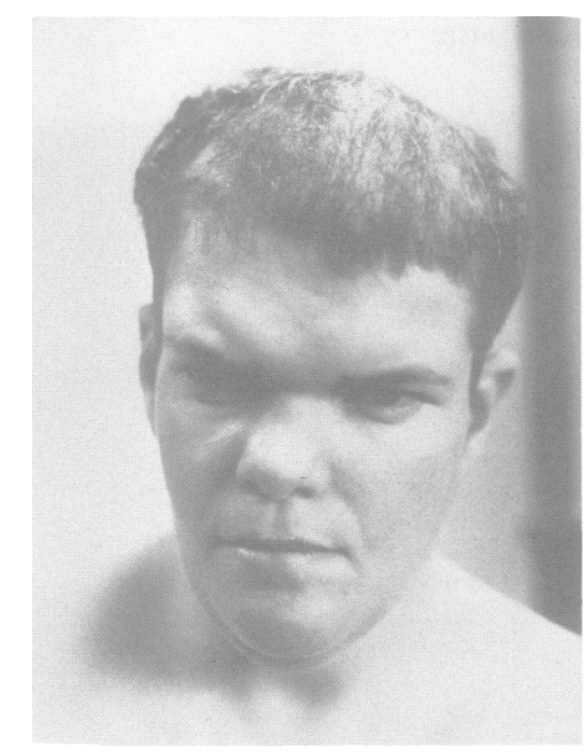

Fig. 2 Case 
which was displaced to the ulnar side, but lacked a simian crease. The right digits had 3 ulnar loops and 2 whorls with a total ridge count of 29 . The left hand had 3 ulnar loops and 2 whorls with a total count of 35 . The total ridge count of all 10 digits was 64 .

\section{CASE 2}

The axial palmar triradius of both hands was in the $t^{\prime}$ position and displaced to the ulnar side of the palms. Both hands had a simian crease. The right hand had 3 radial loops and 2 ulnar loops on the digits with a total ridge count of 34 . The left hand had 2 arches, 2 ulnar loops, and 1 whorl on the digits with a total ridge count of 24. The total digital ridge count of all 10 digits was 58 .

\section{Chromosome analyses}

Peripheral blood lymphocyte chromosome analysis used a modification of the trypsin-Giemsa technique.

\section{A S E 1}

Eighteen cells on peripheral blood analysis had 49, XXXXY karyotype (Fig. 3). All 20 cells from a skin fibroblast culture showed the same pattern. Sex chromatin studies showed the following: hair root sheath analysis showed $5 \%$ of cells with one X chromatin body, $34 \%$ with two, and $61 \%$ with three $\mathrm{X}$ chromatin bodies. Three neutrophils out of 100 cells had a single drumstick.
C A S E 2

Thirty-one cells had 49,XXXXY karyotype (Fig. 4); 7 cells with less than 49 chromosomes contained the same abnormality and otherwise showed random chromosome loss which was attributed to technical artefact. All 17 cells from a skin fibroblast study showed the same XXXXY karyotype. Sex chromatin studies disclosed the following: drumstick analysis of 100 peripheral blood neutrophils showed 6 with one drumstick and 1 with two drumsticks. Hair root sheath analysis disclosed $21 \%$ cells and one X chromatin body, $23 \%$ cells with two, and $39 \%$ with three $\mathrm{X}$ chromatin bodies. Buccal smear on the right showed $30 \%$ cells with one X chromatin body, $20 \%$ with two, and $3 \%$ with three $X$ chromatin bodies. Buccal smear on the left indicated $27 \%$ of cells with one $\mathrm{X}$ chromatin body, $15 \%$ with two, and none with three $\mathrm{X}$ chromatin bodies.

\section{Endocrine studies}

Basal serum $\mathrm{T}_{4}, \mathrm{~T}_{3}, \mathrm{TSH}$, growth hormone, prolactin, and oestradiol were normal in both patients; serum LH and FSH levels were raised in both cases, while serum testosterone was low for adult men (Table 2).

\section{Discussion}

Since first described by Fraccaro et al. in 1960, the 49, XXXXY syndrome has been evaluated by several

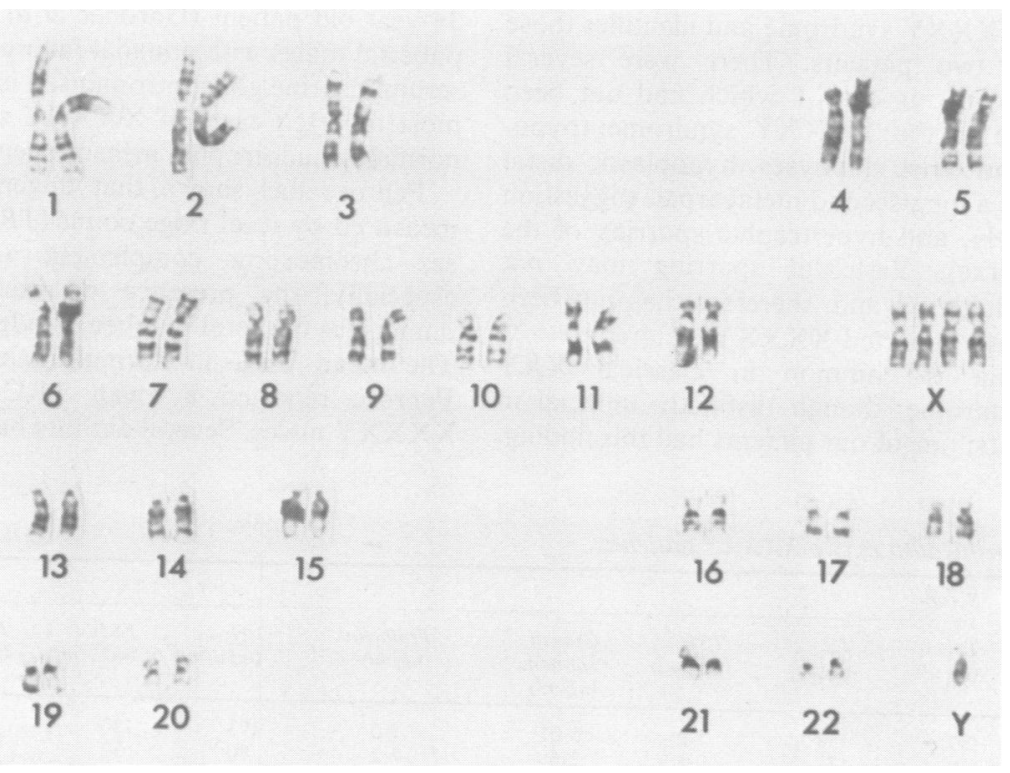

Fig. 3 Trypsin-Giemsa banded karyotype of case 1. 


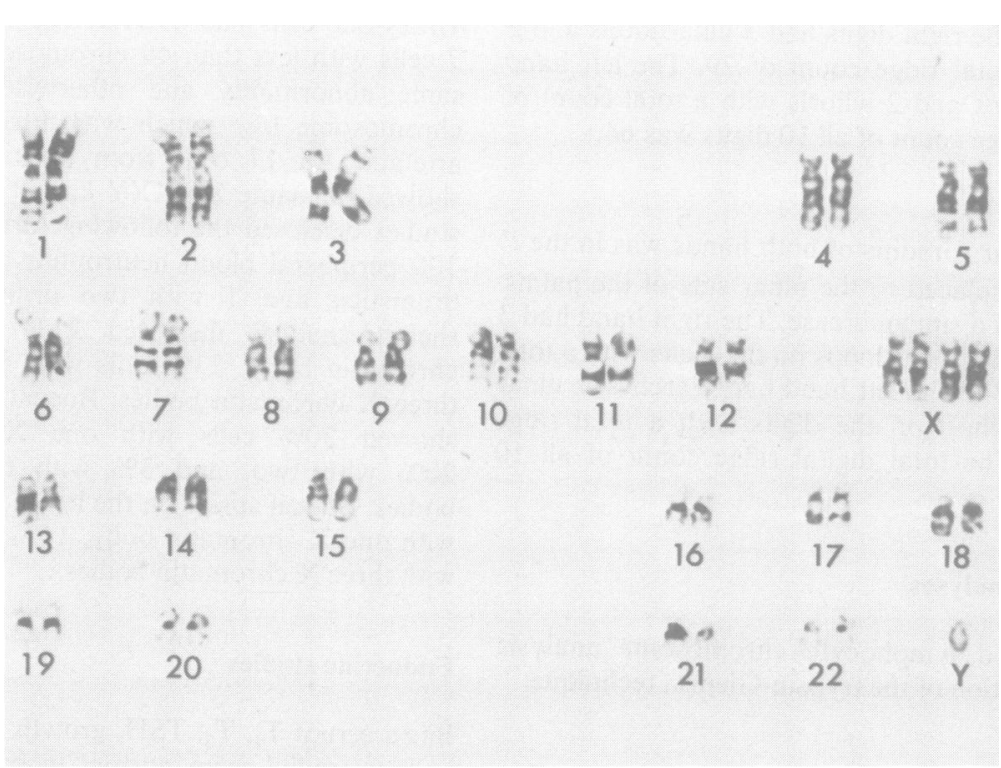

Fig. 4 Trypsin-Giemsa banded karyotype of case 2.

investigators on clinical, endocrine, dermatoglyphic, genetic, and radiographic bases. Distinctive patterns have appeared in the presentation of these patients; our two patients had some common characteristics of this syndrome but were lacking others (Table 1). Table 1 also summarises the more common radiological features in the XXXXY syndrome and identifies those present in our two patients. There were several unusual findings in our case 1 which had not been described before in the XXXXY syndrome (hypoplastic elbow and wrist epiphyses, hypoplastic distal phalangeal tufts, a long second metacarpal, suggestion of arachnodactyly, and hypertrophic spurring of the thoracic vertebrae). Vertebral spurring may not develop until adulthood and, therefore, has not been found in previously reported XXXXY children.

Gynaecomastia is common in classical XXY Klinefelter's syndrome, though distinctly unusual in XXXXY patients; one of our patients had this finding.
Gorlin (1974) stated that patients with XXXXY have hypogonadism but do not have raised gonadotrophins; findings in our patients contradict this. Both of our patients had very low testosterone values and raised LH and FSH levels. Our observation agrees with Gardner's description of a raised plasma LH in a $\triangle$ 34-year-old patient (Gardner et al., 1972). Since pre- $\overrightarrow{\vec{B}}$ pubertal males with gonadal failure do not have raised 3 serum or urine gonadotrophins, it is not surprising that most reported cases of XXXXY syndrome have had normal gonadotrophin measurements.

Penrose has shown that fingertip pattern size as measured by total ridge count (TRC) is influenced by sex chromosome complement and that in males, especially, the presence of each $\mathrm{X}$ chromosome 0 diminishes the total number of ridges (Penrose, 1967). The mean TRC in normal males is 145.0 ridges. 0 Penrose reported a mean TRC of 51 ridges for $D$ XXXXY males. Several authors have reported normal

Table 2 Endocrine data in two $X X X X Y$ patients

\begin{tabular}{|c|c|c|c|c|c|c|c|c|c|}
\hline & \multicolumn{9}{|l|}{ Serum } \\
\hline & $\begin{array}{l}T_{4} \\
(\mu g / d l)\end{array}$ & $\begin{array}{l}T_{3} \\
(n g / d l)\end{array}$ & $\begin{array}{l}T S H \\
(\mu U / m l)\end{array}$ & $\begin{array}{l}\text { Growth } \\
\text { hormone } \\
(n g / m l)\end{array}$ & $\begin{array}{l}\text { Prolactin } \\
(n g / m l)\end{array}$ & $\begin{array}{l}L H \\
(m I U / m l)\end{array}$ & $\begin{array}{l}F S H \\
(m I U / m l)\end{array}$ & $\begin{array}{l}\text { Testosterone } \\
(n g / d l)\end{array}$ & $\begin{array}{l}\text { Oestradiol } \\
(\mathrm{pg} / \mathrm{ml})\end{array}$ \\
\hline $\begin{array}{l}\text { Case } 1 \\
\text { Case } 2 \\
\text { Normal adult } \\
\text { male range }\end{array}$ & $\begin{array}{l}9 \cdot 3 \\
6 \cdot 9 \\
4 \cdot 5-12\end{array}$ & $\begin{array}{l}158 \\
137 \\
80-205\end{array}$ & $\begin{aligned} & 1.2 \\
< & 0.3 \\
< & 0.3-5.0\end{aligned}$ & $\begin{aligned}<0.01 & \\
& 2.6 \\
<5 & \end{aligned}$ & $\begin{array}{r}7.0 \\
7.2 \\
<12\end{array}$ & $\begin{array}{r}173 \\
80 \\
3-20\end{array}$ & $\begin{array}{r}120 \\
32 \\
3-20\end{array}$ & $\begin{array}{l}54 \\
20 \\
200-1200\end{array}$ & $\begin{array}{l}<23 \\
<30 \\
<45\end{array}$ \\
\hline
\end{tabular}


TRC in their XXXXY patients (Zaleski et al., 1966; Korten et al., 1975), while others have documented a decreased TRC, ranging from 28 to 118 ridges. In our patients, the TRCs were 64 and 58 ridges, in good agreement with Penrose's observed mean for 9 patients with an XXXXY chromosome complement.

Before this paper, leucocyte culture autoradiographic techniques with tritiated thymidine have shown the XXXXY chromosome pattern in several studies, but only de la Chapelle and Schroder (1973) and Korten et al. (1975) reported the use of trypsin-Giemsa banding techniques.

The authors wish to thank Alan Reed, Nancy Meyer, Jung Park, and Jacqueline Briggs for assistance with the hormone determinations; Dr Richard Gold, Department of Radiology, UCLA Center for Health Sciences for his aid in $x$-ray interpretation; and $\mathrm{Dr}$ Helga Muller for assistance with the cytogenetic analyses.

Charles L. Levy, Robert S. Sparkes, and HAROLD E. CARLSON

\section{Medical and Research Services, Veterans Administration, Wadsworth Hospital Center; and Departments of Medicine and Pediatrics, UCLA School of Medicine, Los Angeles, California, U.S.A.}

\section{References}

Chopra, I. J., Ho, R. S., and Lam, R. (1972). An improved radioimmunoassay of triiodothyronine in serum: its application to clinical and physiological studies. Journal of Laboratory and Clinical Medicine, 80, 729-739.

Chopra, I. J. (1972). A radioimmunoassay for measurement of thyroxine in unextracted serum. Journal of Clinical Endocrinology and Metabolism, 34, 938-947.

de la Chapelle, A., and Schroder, J. (1973). Autoradiographically identified karyotype 49, XXXXY, t $(4 ; 11)$ (q 35; q 23) confirmed by banding. Hereditas, 74, 291-292.

Fraccaro, M., Kaijser, K., and Lindsten, J. (1960). A child with 49 chromosomes. Lancet, 2, 899-902.

Gardner, R. J. M., Sands, U. E., Veale, A. M. O., Howarth, D. A. and Parslow, M. I. (1972). XXXXY syndrome with mosaicism: case report. New Zealand Medical Journal, 74, 22-27.

Gorlin, R. J. (1974). Clinical manifestations of chromosome disorders. In Human Chromosome Methodology, p. 220. Ed. by J. J. Yunis. Academic Press, New York.

Houston, C. S. (1967). Roentgen findings in XXXXY chromosome anomaly. Canadian Radiologists Association Journal, 18, 258-267.

Korten, J. J., Van Dorp, A., Hustinx, Th. W. J., Scheres, J. M. J., and Rutten, F. J. (1975). Self-mutiliation in a case of 49 , XXXXY chromosomal constitution. Journal of Mental Deficiency Research, 19, 63-71.

Pekary, A. E., Hershman, J. M., and Parlow, A. F. (1976). A sensitive and precise radioimmunoassay for human thyroid stimulating hormone. Journal of Clinical Endocrinology and Metabolism, 41, 676-684.

Penrose, L. S. (1967). Fingerprint pattern and the sex chromosomes. Lancet, 1, 298-300.
Schalch, D. S., and Parker, M. L. (1964). A sensitive double antibody immunoassay for human growth hormone in plasma. Nature, 203, 1141-1142.

Sinha. Y. N., Selby, F. W., Lewis, U. J., and Vanderlaan, W. P., (1974). A homologous radioimmunoassay for human prolactin. Journal of Clinical Endocrinology and Metabolism, 36, 509-516.

Tenbrinck, M. S., Boyd, J. H., and Buchin, S. Y. (1976). The chromosome 49,XXXXY syndrome. Report of a case in an adult. Arizona Medicine, 33, 546-551.

Zaleski, W. A., Houston, C. S., and Pozsonyi, J. (1966). The XXXXY chromosome anomaly: report of 3 new cases and review of 30 cases from the literature. Canadian Medical Association Journal, 94, 1143-1154.

Requests for reprints to Dr Harold E. Carlson, Endocrinology Section, Wadsworth VA Hospital, Wilshire and Sawtelle Blvds, Los Angeles, California 90073, U.S.A.

\section{Dissociation as probable origin of mosaic $45, \mathrm{XY}, \mathrm{t}(15 ; 21)$ / $46, X Y, i(21 q)$}

SUMMARY A patient is described with some features of Down's syndrome and a 45,XY, $\mathrm{t}(15 ; 21)(15 \mathrm{qter} \rightarrow 15 \mathrm{p} 13:: 21 \mathrm{p} 11 \rightarrow 21 \mathrm{qter}) / 46$, $\mathrm{XY}, \mathrm{i}(21)$ (qter $\rightarrow$ cen $\rightarrow$ qter) karyotype. Two mechanisms are proposed for the origin of the mosaicism, one assuming the dissociation of a translocation $(15 ; 21)$ chromosome already present in the zygote, and the other involving a chromatid translocation in a $46, \mathrm{XY}$ zygote. The possible independent origin of the two cell lines is also considered.

\section{Case report}

The propositus (GB 260674) was born at term after an uneventful pregnancy and normal delivery; birthweight was $3400 \mathrm{~g}$. The parents were in good health and both were 32 years of age. The only sister, born in 1972, was normal. There was no history of abortions or other cases of congenital abnormalities in the family.

Examination at 2 years of age showed a healthy boy with normal neuropsychomotor development. His height was $86 \mathrm{~cm}$, and his head circumference $47 \mathrm{~cm}$. $\mathrm{He}$ had a flat face with depressed supraorbital ridges, discrete mongoloid slanting of the palpebral fissures, and bluish sclera. There was partial syndactyly between the 3 rd and 4 th digits on the right hand. The rest of the physical examination was normal. 